\title{
ARTICLES
}

\section{Sanfilippo type B syndrome (mucopolysaccharidosis III B): allelic heterogeneity corresponds to the wide spectrum of clinical phenotypes}

\author{
B irgit Weber ${ }^{1}$, Xiao-H ui Guo ${ }^{1}$, Wim J Kleijer ${ }^{2}$, Jacques J P van de Kamp², \\ Ben JHM Poorthuis ${ }^{4}$ and John J Hopwood ${ }^{1}$ \\ ${ }^{1}$ L ysosomal D iseases Research U nit, D epartment of Chemical Pathology, Women's and Children's H ospital, North \\ A delaide, A ustralia \\ ${ }^{2}$ D epartment of Clinical G enetics, U niversity H ospital, R otterdam \\ ${ }^{3} \mathrm{~L}$ eiden $U$ niversity $M$ edical $C$ entre, $L$ eiden \\ ${ }^{4} U$ niversity of $L$ eiden, D epartment of Pediatrics, L eiden, The N etherlands
}

\begin{abstract}
Sanfilippo B syndrome (mucopolysaccharidosis IIIB, M PS IIIB) is caused by a deficiency of $\alpha-\mathrm{N}$-acetylglucosaminidase, a lysosomal enzyme involved in the degradation of heparan sulphate. A ccumulation of the substrate in lysosomes leads to degeneration of the central nervous system with progressive dementia often combined with hyperactivity and aggressive behaviour. A ge of onset and rate of progression vary considerably, whilst diagnosis is often delayed due to the absence of the pronounced skeletal changes observed in other mucopolysaccharidoses. Cloning of the gene and CD NA encoding $\alpha-\mathrm{N}$-acetylglucosaminidase enabled a study of the molecular basis of this syndrome. We were able to identify $\mathbf{3 1}$ mutations, 25 of them novel, and two polymorphisms in the $\mathbf{4 0}$ patients mostly of $A$ ustralasian and D utch origin included in this study. The observed allellic heterogeneity reflects the wide spectrum of clinical phenotypes reported for MPS IIIB patients. The majority of changes are missense mutations; also four nonsense and nine frameshift mutations caused by insertions or deletions were identified. 0 nly five mutations were found in more than one patient and the observed frequencies are well below those observed for the common mutations in M PS IIIA . R 643C and R 297X each account for around 20\% of MPS IIIB alleles in the Dutch patient group, whilst $R$ 297X, P 521L, R 565W and R 626X each have a frequency of about $6 \%$ in A ustralasian patients. R 643C seems to be a Dutch MPS IIIB allele and clearly confers the attenuated phenotype. O ne region of the gene shows a higher concentration of mutations, probably reflecting the instability of this area which contains a direct repeat. Several arginine residues seem to be 'hot-spots' for mutations, being affected by two or three individual base pair exchanges.
\end{abstract}

Keywords: Sanfilippo type B syndrome; mucopolysaccharidosis IIIB; MPS; common mutations; $\alpha-\mathrm{N}$-actylglucosaminidase

Correspondence: Dr John J. Hopwood, Lysosomal D iseases R esearch U nit, D epartment of Chemical Pathology, Women's and Children's Hospital, 72 King William Road, North A delaide, South A ustralia 5006, A ustralia. Tel: 6188204 6153; Fax: 6188204 7100; E-mail: jhopwood@medicine adelaide.edu.au

R eceived 6 M ay 1998; revised 9 J une 1998; accepted 19 J une 1998 


\section{Introduction}

In Sanfilippo syndrome, also known as mucopolysaccharidosis III (MPS III), the impaired lysosomal degradation and subsequent lysosomal storage of heparan sulphate causes severe central nervous system degeneration resulting in progressive dementia often combined with hyperactivity and aggressive behaviour. ${ }^{1}$ Clinical onset is usually marked by delayed speech development by the age of two to three years, together with sleep disturbance, hirsutism and diarrhoea. MPS IIIB is one of the four recognised biochemical subtypes of this disease. E ach of the M PS III types is inherited as an autosomal recessive disorder with some differences among the four types. ${ }^{1}$ M PS III may be underdiagnosed in patients with less severe mental retardation since in contrast to other M PS disorders, Sanfilippo syndrome patients often have little somatic disease with the coarse facial features that are prominent in the other M PS often absent in adults. The high incidence of false negative results in the urinary screening test for mucopolysaccharides by some methods increases the difficulties in diagnosing the rare less severe and slowly evolving cases. ${ }^{1}$ These slower-progressing disease phenotypes should more accurately be described as the attenuated form of Sanfilippo syndrome. ${ }^{2,3}$

MPS IIIA patients are reported to have the most severe of the four Sanfilippo subtypes with earlier onset of symptoms and more rapid progression, ${ }^{1}$ whereas M PS IIIB patients display a wider clinical heterogeneity with attenuated and severe cases reported even within the same sibship. ${ }^{2}$ The combined incidence of all four Sanfilippo subtypes has been estimated at 1:24000 and MPS IIIB is the most common subtype in Greece, ${ }^{5,6}$ whereas in Northern Europe MPS IIIA seems to be more predominant. ${ }^{7}$ I n A ustralia M PS IIIA and IIIB have incidences of about 1 in 114000 and 1 in 211000 , respectively (M eikle $\mathrm{P}, 1998$ unpublished observations), reflecting the pattern of migration from Northern Europe (predominantly Great Britain and I reland) and from Southern Europe (mainly I taly and G reece).

MPS III may result from a deficiency in one of four enzymes involved in the degradation of heparan sulfate, with $\alpha$-N -acetylglucosaminidase (NA G LU, E C 3.2.1.50) being deficient in MPS IIIB. A partial CDNA clone had been characterised earlier ${ }^{8}$ and recently full-length CDNA clones encoding NAGLU were isolated (GenB ank $U 40846^{9}$ and $G$ enB ank $U 43572^{10}$ ). The structure of the corresponding NAGLU gene on chromosome $17 q 21.1$ was predicted by alignment of the CDNA sequence with the genomic sequence of the $5^{\prime}$-flanking region of the $\beta$-HSD gene ( $G$ enBank U 34879). The presence of different genotypes, seen to segregate between black and white families ${ }^{11,12}$ suggested the presence of NAGLU polymorphism. Vance et al pointed out that alleles with high enzymatic activity could interfere with the identification of heterozygotes ${ }^{13}$ and this might have occurred in the case described by Pande et al. ${ }^{14}$ In this family some of the heterozygotes had normal levels of NAGLU activity presumably due to a 'hyperactive' allele.

R ecently several mutations causing MPS IIIB have been published. ${ }^{3,10,15,16}$ We now report the analysis of the NAGLU alleles of 40 M PS IIIB patients revealing strong heterogeneity with 25 novel mutations and two polymorphisms identified, including one mutation (R 643C) common amongst Dutch patients that is clearly associated with the attenuated form of the disease.

\section{Materials and Methods}

\section{Sample Preparation and PCR Amplification}

Skin fibroblasts from patients and normal controls were cultured and genomic DNA isolated as described elsewhere. ${ }^{17}$ Clinical diagnosis was confirmed by skin fibroblasts having very low or non-detectable levels of NA GLU activity. ${ }^{18,19}$ Exons were amplified from genomic DNA as shown in Table 1 which summarises primers, PCR and SSCP gel electrophoresis conditions. PCR reactions were carried out in $1 \times$ Biotech buffer $\left(67 \mathrm{~mm}\right.$ Tris- $\mathrm{HCl} \mathrm{pH} 8.8,16.6 \mathrm{mM} \mathrm{NH} \mathrm{SO}{ }_{4}$, $0.45 \%$ Triton X-100, $0.2 \% \mathrm{mg} / \mathrm{ml}$ gelatin) $2.5 \mathrm{~mm} \mathrm{M} \mathrm{gCl}{ }_{2}$, $400 \mu \mathrm{M}$ dNTPs, $1 \cup$ Taq polymerase (Boehringer M annheim, G ermany), $200 \mathrm{ng}$ of each primer and with or without (see Table 1) $10 \%$ dimethylsulfoxide using the tube control option of a $\mathrm{H}$ ybaid $\mathrm{O}$ mniG ene Thermocycler. A fter initial denaturation of $2 \mathrm{~min}$ at $95^{\circ} \mathrm{C}, 35 \mathrm{cycles}$ of $30 \mathrm{~s}$ at $95^{\circ} \mathrm{C}, 45 \mathrm{~s}$ at annealing temperature (see Table 1 ) and $30 \mathrm{~s}$ of extension at $72^{\circ} \mathrm{C}$ followed, with a final extension step for $2 \mathrm{~min}$ at $72^{\circ} \mathrm{C}$. A round $30 \mathrm{ng}$ of genomic DNA were used as template.

\section{SSCP Analysis}

Fragment 5 was digested with $B \mathrm{Cl} I$, fragment $6 \mathrm{II} / \mathrm{II}$ with $\mathrm{A}$ va II and fragment $6 \mathrm{~V}$ with $\mathrm{H}$ ind II before SSCP analysis. $5 \mu \mathrm{I}$ of PCR product and $4 \mu \mathrm{l}$ of sample buffer (95\% formamide, $20 \mathrm{~mm}$ EDTA, $0.005 \%$ Bromophenol blue, $0.05 \%$ Xylene cyanol FF) were mixed, heated to $95^{\circ} \mathrm{C}$ for 4 min and kept on ice before being loaded on to an $8 \%, 0.8 \mathrm{~mm}$ thick polyacrylamide gel (acrylamide/bisacrylamide ratio: 41.5:1 with or without $5 \%$ glycerol, see Table 1). Electrophoresis of the fragments was performed in $1 \times T B E$ buffer on an $|B|$ sequencing unit for $15 \mathrm{~h}$ at $20 \mathrm{~W} / 450 \mathrm{~V}$. DNA bands were visualised by staining with silver.

\section{Sequencing}

Fragments with an altered band pattern were identified and the corresponding exon amplified by PCR . A fter purification 
Table 1 PCR and SSCP conditions

\begin{tabular}{|c|c|c|c|c|c|c|c|}
\hline Exon & Primer & Position & Sequence & $\begin{array}{l}\text { Product } \\
\text { (bp) }\end{array}$ & $\begin{array}{l}\text { A nnealing } \\
\text { temp. }\left({ }^{\circ} \mathrm{C}\right)\end{array}$ & $\begin{array}{l}\text { D M SO } \\
10 \%\end{array}$ & $\begin{array}{l}\text { SSCP gel } \\
10 \% \text { glycerol }\end{array}$ \\
\hline 11 & $\begin{array}{l}\text { ng } 1 \\
\text { NAG } 45\end{array}$ & $\begin{array}{l}10861-10883 \\
11141-11118\end{array}$ & $\begin{array}{l}\text { 5'-CCTTCG G G TCACGTG GCCG G A G -3' } \\
5^{\prime}-\text {-G GT TCCA A G CCCG G CTTG G CA GC-3' }\end{array}$ & 280 & 65 & + & - \\
\hline 111 & $\begin{array}{l}\text { NAG 38* } \\
\text { ng } 2\end{array}$ & $\begin{array}{l}11086-11110 \\
11415-11395\end{array}$ & $\begin{array}{l}5^{\prime}-\text { CA A CTTCTCCG TG TCG G T G G A G CG -3' } \\
5^{\prime}-\text {-G CTCA G CCTCCCG ATTTG G G T-3' }\end{array}$ & 329 & 55 & + & - \\
\hline 2 & ng 3 & $\begin{array}{l}12014-12033 \\
12291-12268\end{array}$ & $\begin{array}{l}\text { 5'-TTG TTCCA G G G CCG T G G A C C C-3' } \\
5^{\prime}-\mathrm{G} \text { G G CG G G TGA A A A CA CCTA CG GT G -3' }\end{array}$ & 277 & 58 & - & + \\
\hline 3 & $\begin{array}{l}\text { ng } 5 \\
\text { ng } 6\end{array}$ & $\begin{array}{l}12944-12968 \\
13248-13227\end{array}$ & $\begin{array}{l}\text { 5'-G A A T G G TT G TT G A A T G A A T G A - } 3^{\prime} \\
5^{\prime}-A \text { G CCCTG G G G CCG G CCTA A TA C- }-3^{\prime}\end{array}$ & 304 & 55 & - & - \\
\hline 4 & $\begin{array}{l}\text { ng } 7 \\
\text { ng } 8\end{array}$ & $\begin{array}{l}13269-13289 \\
13517-13496\end{array}$ & $\begin{array}{l}\text { 5'-G C G T G TA TCCT G G G A G A T G A G -3' } \\
5^{\prime}-\text {-CCA G A G CTTA A G TTTTTA A G TC-3' }\end{array}$ & 248 & 58 & - & + \\
\hline 5 & $\begin{array}{l}\text { NAG it } \\
\text { ng } 9\end{array}$ & $\begin{array}{l}15574-15590 \\
15981-15961\end{array}$ & $\begin{array}{l}\text { 5'-G G T G A A CA CTATG G CG G -3' } \\
5^{\prime}-\mathrm{G} \text { G CATTATTCCA GTCCCTCT }-3^{\prime}\end{array}$ & 407 & 55 & - & + \\
\hline 61 & $\begin{array}{l}\text { ng } 10 \\
\text { NAG } 12\end{array}$ & $\begin{array}{l}17641-17660 \\
17966-17943\end{array}$ & $\begin{array}{l}\text { 5'-G A A CA TTCCCT G G G CCCTCT G-3' } \\
5^{\prime}-\mathrm{TCT} \text { G G G CCTCCGTTCA CA G CCTCT-3' }\end{array}$ & 325 & 60 & - & + \\
\hline 611 & $\begin{array}{l}\text { NAG } 42 \\
\text { NAG } 49\end{array}$ & $\begin{array}{l}17862-17882 \\
18168-18148\end{array}$ & $\begin{array}{l}\text { 5'-CA CT G CCTCCTTCCA G G G CCA - } 3^{\prime} \\
5^{\prime}-\text {-CT CCTCG CT G CCCCT G C G TC- } 3^{\prime}\end{array}$ & 306 & 60 & - & - \\
\hline $6 \mathrm{III}$ & $\begin{array}{l}\text { NAG } 42 \\
\text { CNBr 3n }\end{array}$ & $\begin{array}{l}17862-17882 \\
18339-18316\end{array}$ & $\begin{array}{l}\text { 5'-CA CT G CCTCCTTCCA G G G CCA -3' } \\
\text { 5'-G G T G G CCA G G GA G G G A G CA GATG T-3' }\end{array}$ & 477 & 60 & - & - \\
\hline $6 \mathrm{IV}$ & $\begin{array}{l}\text { CNBr3C } \\
\text { CNBr3 }\end{array}$ & $\begin{array}{l}18310-18330 \\
18620-18597\end{array}$ & $\begin{array}{l}\text { 5'-CTG GT G CTCA CA TCT G CTCCCTCC - } 3^{\prime} \\
5^{\prime}-A \text { G CT G GTA G C G G CT G TTCT G CTCG -3' }\end{array}$ & 310 & 60 & - & + \\
\hline $6 \mathrm{~V}$ & $\begin{array}{l}\text { NAG } 44 \\
\text { NAG } 48\end{array}$ & $\begin{array}{l}18568-18588 \\
18990-18970\end{array}$ & 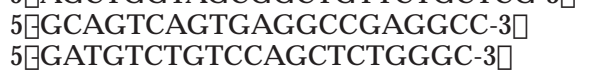 & 422 & 60 & - & $-1+$ \\
\hline $6 \mathrm{VI}$ & $\begin{array}{l}\text { NAG } 47 \\
\text { ng } 11\end{array}$ & $\begin{array}{l}18918-18939 \\
19181-19157\end{array}$ & $\begin{array}{l}\text { 5'-GATTCG CCA CCA CTG G G CCTTG -3' } \\
5^{\prime}-\text {-CCCA A G CG T G G CA G CA G T G A CCTTC-3' }\end{array}$ & 263 & 60 & - & - \\
\hline 1 & $\begin{array}{l}\text { ng } 1 \\
\text { ng } 2\end{array}$ & $\begin{array}{l}10861-10883 \\
11415-11395\end{array}$ & $\begin{array}{l}5^{\prime}-C \text { CTTCG G G TCA C G T G G C C G G A G -3' } \\
5^{\prime}-\text {-G CTCA G CCTCCCGATTTG G G T-3' }\end{array}$ & 554 & 55 & - & $\begin{array}{l}\text { sequencing } \\
\text { only }\end{array}$ \\
\hline 6 & $\begin{array}{l}\text { ng } 10 \\
\text { ng } 11\end{array}$ & $\begin{array}{l}17641-17660 \\
19181-19157\end{array}$ & 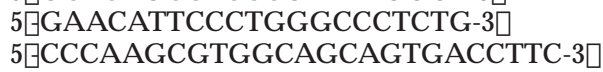 & 1540 & 65 & - & $\begin{array}{l}\text { sequencing } \\
\text { only }\end{array}$ \\
\hline
\end{tabular}

Positions of primers are given according to database entryG enB ank U 34879. *O ligonucleotide NAG 38 is mismatched at the second position due to a sequencing error but worked in the PCR .

of the PCR product on QIA quick PCR purification columns ( $Q$ iagen, Victoria, A ustralia) exons were sequenced using the D ye terminator Cycle Sequencing kit (Perkin E Imer) according to the manufacturer's instructions. Direct sequencing of fragments used for SSCP analysis was performed for exon 2, 4 and 5 . Sequencing products were analysed on an A BI Prism sequencer model 737A by the U niversity of Queensland DNA Sequencing Facility, B risbane. In most cases nested primers were used for sequencing except for exons 2 and 4, where only the PCR primers were available. Sequence alterations were verified by sequencing the opposite strand and, where possible, restriction digest of an independent second PCR product or allele specific oligonucleotide hybridisation for missense and nonsense mutations. D eletions and insertions were confirmed by sequencing.

\section{Allele-Specific Oligonucleotide Hybridisation}

A SO hybridisation was performed as described previously. ${ }^{17}$ The oligonucleotides and washing conditions are summarised in Table 2.

\section{Restriction Analysis}

A $15 \mu \mathrm{l}$ aliquot of a $50 \mu \mathrm{l}$ PCR reaction was incubated with the appropriate restriction enzyme according to manufacturer's instructions. Fragments were separated on $2 \%$ agarose gels and stained with ethidium bromide. Table 3 shows the different enzymes used for identification of the mutations.

\section{Patients and Control Groups}

The patients included in this study, their origin, the age at diagnosis and their clinical phenotype are summarised in Table 4. A Itogether 40 patients were analysed, 13 of them were from The N etherlands and 25 from A ustralasia, predominantly Caucasians. O ne patient was from Norway ${ }^{14}$ and one from the USA. ${ }^{20}$ As control, the NAGLU gene of 72 unaffected individuals was amplified and screened for the identified sequence changes. The control group consisted of 28 individuals from Australasia and 44 from The Netherlands.

\section{Sequence Alignments}

A non-redundant database compiled from the entries of GenBank and EMBL databases, including updates (as of 17 February 1998) at the A ustralian N ational G enomic Information Service (ANGIS), was searched for NAGLU-related sequences with the TBLA STN local alignment too ${ }^{21}$ which screens the nucleotide database entries translated into all six reading frames with the protein sequence of the query. The number of alignments per clone varied between 1 and 17 . In the analysis only alignments with the same strand in all three reading frames were included to allow for frameshifts by introns and/or sequencing errors. In case of overlapping or 
Table 2 A SO primers and washing conditions

\begin{tabular}{|c|c|c|}
\hline M utation & A SO primer & Washing conditions \\
\hline$\overline{\mathrm{F} 48 \mathrm{~L}}$ & $\begin{array}{l}\text { wt 5'-CCGACTTCTCCGTGTC-3' } \\
\text { mut 5'-CCGACTTATCCGTGTC-3' }\end{array}$ & $1 \times \mathrm{SSC} / 0.1 \% \mathrm{SDS} 60^{\circ} \mathrm{C}$ \\
\hline G 292R & $\begin{array}{l}\text { wt 5'-CCATCA TCG G G A G C CTC-3' } \\
\text { mut 5'-C CATCATCA G GA G CCTC-3' }\end{array}$ & $1 \times \mathrm{SSC} / 0.1 \% \operatorname{SDS} 65^{\circ} \mathrm{C}$ \\
\hline R 297X & $\begin{array}{l}\text { wt 5'-CTTCCTGCGA G A G CT GAT-3' } \\
\text { mut 5'-C 6TTCCTGTGA GA GCT GAT-3' }\end{array}$ & $1 \times \mathrm{SSC} / 0.1 \%$ SD S $65^{\circ} \mathrm{C}$ \\
\hline V 334F & $\begin{array}{l}\text { wt 5'-CA CT G CCG TCTATG A G -3' } \\
\text { mut 5'-CA CT GCCTTCTATG A G-3' }\end{array}$ & $1 \times \mathrm{SSC} / 0.1 \% \mathrm{SDS} 50^{\circ} \mathrm{C}$ \\
\hline W 404X & $\begin{array}{l}\text { wt 5'-CCTTCATCT G G T G CA T G C-3' } \\
\text { mut 5'-C } 5^{\prime} \text {-CTTCATCTA G T G CATG C-3' }\end{array}$ & $1 \times \mathrm{SSC} / 0.1 \% \mathrm{SDS} 60^{\circ} \mathrm{C}$ \\
\hline F 410S & $\begin{array}{l}\text { wt 5'-CA CA A CTTTG G G G G A A A C- } 3^{\prime} \\
\text { mut 5'-CACA ACTCG G G G A A A C-3' }\end{array}$ & $1 \times \mathrm{SSC} / 0.1 \% \mathrm{SDS} 55^{\circ} \mathrm{C}$ \\
\hline W 494X & $\begin{array}{l}\text { wt 5'-G G CA G C G T G GA G G CTA C-3' } \\
\text { mut 5'-G G CA G C GTG A A G G CTA C-3' }\end{array}$ & $0.5 \times \mathrm{SSC} / 0.1 \% \mathrm{SD} \mathrm{S} 65^{\circ} \mathrm{C}$ \\
\hline P521L & $\begin{array}{l}\text { wt 5'-CA G G C G G C C G TCCCTA C-3' } \\
\text { mut 5'-CA G G C G G CTG TCCCTA C-3' }\end{array}$ & $0.5 \times \mathrm{SSC} / 0.1 \% \operatorname{SDS} 65^{\circ} \mathrm{C}$ \\
\hline L 560P & $\begin{array}{l}\text { wt 5'-CTACG A C CT G CTG G A C-3' } \\
\text { mut 5'-CTACG A C CC C CT G G A C-3' }\end{array}$ & $1 \times \mathrm{SSC} / 0.1 \% \operatorname{SDS} 45^{\circ} \mathrm{C}$ \\
\hline R 565P & $\begin{array}{l}\text { wt 5'-CCTCA CT C G G CA G G CA G -3' } \\
\text { mut 5'-CCTCACTCCG CA G G CA G-3' }\end{array}$ & $0.5 \times \mathrm{SSC} / 0.1 \% \operatorname{SDS} 65^{\circ} \mathrm{C}$ \\
\hline R 565W & $\begin{array}{l}\text { wt 5'-CCTCA CTCG G CA G G CA G -3' } \\
\text { mut 5'-CCTCACTTG G CA G G CA G-3' }\end{array}$ & $0.5 \times \mathrm{SSC} / 0.1 \% \operatorname{SDS} 65^{\circ} \mathrm{C}$ \\
\hline R 643C & $\begin{array}{l}\text { wt 5'-CA G A A CA G C C C CTA C CA G - } 3 \text { ' } \\
\text { mut 5'-CA G A A CA G CTG CTA C CA G -33' }\end{array}$ & $0.5 \times \mathrm{SSC} / 0.1 \% \operatorname{SDS} 65^{\circ} \mathrm{C}$ \\
\hline R 674C & $\begin{array}{l}\text { wt 5'-CA CCCCTCG CT G G C G G C-3' } \\
\text { mut 5'-CA CCCCTT G CT G G C G G C-3' }\end{array}$ & $0.5 \times \mathrm{SSC} / 0.1 \%$ SD S $60^{\circ} \mathrm{C}$ \\
\hline R 676P & $\begin{array}{l}\text { wt 5'-CT CG CTG G C G G CTTTTCCTG -3' } \\
\text { mut 5'-CTCG CT G G CC C CTTTTCCTG -3' }\end{array}$ & $0.5 \times \mathrm{SSC} / 0.1 \% \mathrm{SDS} 65^{\circ} \mathrm{C}$ \\
\hline
\end{tabular}

alternative alignments the one with the higher score was chosen. Smallest sum probabilities of $0-1.2 \mathrm{e}-5$ were considered significant.

\section{Results}

\section{Mutation Screening}

The six exons of the NAG L U gene including the intron/ exon boundaries and $5^{\prime}$ - and $3^{\prime}$ - non-translated regions were amplified by PCR in 12 overlapping PCR fragments. Non-radioactive SSCP analysis and subsequent sequencing of the DNA of 40 MPS IIIB patients revealed 33 different primary sequence changes. Under the given conditions, all missense mutations produced mobility shifts of the heteroduplex bands. However, some of them - R 565P, L560P, P521L, F 410S, V 334F, G 292R, H 248R, G 69S and F 48L, as well as R 297X and $R 626 X$ - failed to produce a different pattern of single stranded DNA bands, whereas mobility shifts of the single-stranded DNA bands were observed in all cases of deletions and insertions.
The majority of changes lead to non-conservative exchanges of amino acids (Table 3 ), one (F 48L) in the pro-peptide and the rest in the mature protein. Two of the amino acid exchanges ( $H 248 R$ and H414R) are conservative.

Four insertions ranging in size from 2 to $25 \mathrm{bp}$ were identified as well as four deletions of 1-10 bp length, and four nonsense mutations. Two of these (R 297X and $R$ 626X) were described previously; ${ }^{10}$ another (W 404X) was also found in a group of European patients (BungeS, 1998 personal communication). The fourth nonsense mutation (W 494X) is novel. A II insertions result in frameshifts and subsequent premature termination, similar to the majority of deletions. However, delA 2100 and del2bp2171 lead to frameshifts that mask the original stop codon and would elongate the gene product by 43 and 80 aa respectively.

A Ithough all intron/exon boundaries as well as the non-translated region $5^{\prime}$ and $3^{\prime}$ of the coding sequence were included in the analysis, no splice-site, initiation or polyadenylation mutations were detected.

To identify possible polymorphism we screened more than 140 control chromosomes for these sequence changes by A SO hybridisation or, where possible, by 
Table 3 Mutations and polymorphisms

\begin{tabular}{|c|c|c|c|c|c|}
\hline Mutation & $\begin{array}{l}\text { Number of alleles found } \\
\text { (frequency in } \\
\% \text { in Australasian } \\
\text { and Dutch patients) }\end{array}$ & $\begin{array}{l}\text { Sequence } \\
\text { alteration }\end{array}$ & Effect & $\begin{array}{l}\text { Restriction } \\
\text { enzyme }\end{array}$ & $\begin{array}{l}\text { aa conserved in putative } \alpha-\mathrm{N} \text { - } \\
\text { acetylglucosaminidase genes } \\
\text { of other species }\end{array}$ \\
\hline c54g & 2 (homozygous patient) & $\mathrm{GCC} \rightarrow \mathrm{GCG}$ & silent mutation & & \\
\hline F48L & 1 & TTC $\rightarrow$ TTA & non-conservative aa exchange in the propeptide & - & $\mathrm{F}$ in mouse \\
\hline G695 & 1 & $\mathrm{GGC} \rightarrow \mathrm{AGC}$ & non-conservative aa exchange in the mature protein & $-B g l$ I & $\mathrm{G}$ in mouse \\
\hline H227P & 1 & $\mathrm{CAC} \rightarrow \mathrm{CCC}$ & non-conservative aa exchange in the mature protein & +Xmal & $\mathrm{H}$ in mouse; $\mathrm{K}$ in $\mathrm{A}$. thaliana and $\mathrm{C}$. elegans \\
\hline$H 248 R$ & 1 & $\mathrm{CAT} \rightarrow \mathrm{CGT}$ & conservative aa exchange in the mature protein & -NlallI & $\begin{array}{l}\mathrm{H} \text { in mouse; } \mathrm{N} \text { in } \mathrm{A} \text {. thaliana; } \mathrm{F} \text { in } \\
\mathrm{C} \text {. elegans }\end{array}$ \\
\hline G292R ${ }^{a}$ & 1 & GGG $\rightarrow$ AGG & non-conservative aa exchange in the mature protein & - & G in mouse, A. thaliana and C. elegans \\
\hline$R 297 X^{b}$ & $10(\mathbf{A} 8 \% ; \mathbf{D} 23 \%)$ & $\mathrm{CGA} \rightarrow \mathrm{TGA}$ & premature termination after 296 of 743 aa & - & \\
\hline V $334 \mathrm{~F}$ & 2 (homozygous patient) & $\mathrm{GTC} \rightarrow \mathrm{TTC}$ & non-conservative aa exchange in the mature protein & - & $V$ in mouse and $A$. thaliana \\
\hline$W 404 X^{a}$ & 2 (homozygous patient) & TGG $\rightarrow$ TAG & premature termination after 403 of 743 aa & +Bfal & \\
\hline F 410S & 1 & $\mathrm{TTT} \rightarrow \mathrm{TCT}$ & non-conservative aa exchange in the mature protein & - & $\begin{array}{l}\mathrm{F} \text { in mouse, } \mathrm{A} \text {. thaliana, C. elegans } \\
\text { and rice }\end{array}$ \\
\hline H414R & 1 & $\mathrm{CAT} \rightarrow \mathrm{CGT}$ & conservative aa exchange in the mature protein & $-\mathrm{Ncol}$ & $\begin{array}{l}H \text { in mouse; } R \text { in C. elegans; I in } \\
\text { A. thaliana and rice }\end{array}$ \\
\hline W494X & 2 (homozygous patient) & $\mathrm{TGG} \rightarrow \mathrm{TGA}$ & premature termination after 494 of 743 aa & & \\
\hline $\mathrm{P} 521 \mathrm{~L}^{\mathrm{c}}$ & $3(\mathbf{A} 6 \%)$ & $\mathrm{CCG} \rightarrow \mathrm{CTG}$ & non-conservative aa exchange in the mature protein & - & $P$ in mouse \\
\hline L560P & 1 & $\mathrm{CTG} \rightarrow \mathrm{CCG}$ & non-conservative aa exchange in the mature protein & - & $L$ in mouse; $M$ in $A$. thaliana \\
\hline R 565P & 1 & $\mathrm{CGG} \rightarrow \mathrm{CCG}$ & non-conservative aa exchange in the mature protein & - & $\mathrm{R}$ in mouse and $\mathrm{A}$. thaliana \\
\hline R 565W & $3(\mathbf{A} 6 \%)$ & $\mathrm{CGG} \rightarrow \mathrm{TGG}$ & non-conservative aa exchange in the mature protein & - & \\
\hline L617F & 1 & TTG $\rightarrow$ TTC & non-conservative aa exchange in the mature protein & +BstN I & L in C. elegans and rice \\
\hline$R 626 X^{b}$ & $3(\mathbf{A} 6 \%)$ & $\mathrm{CGA} \rightarrow \mathrm{TGA}$ & premature termination after 625 of 743 aa & -Aval & \\
\hline $\mathrm{R} 643 \mathrm{C}$ & 5 (D 19\%) & $\mathrm{CGC} \rightarrow \mathrm{TGC}$ & non-conservative aa exchange in the mature protein & - & $\begin{array}{l}\mathrm{R} \text { in mouse; } \mathrm{A} \text {. thaliana, D. melanogaster } \\
\text { and Dictyostelium; G in C. elegans }\end{array}$ \\
\hline G650E & 1 & $\mathrm{GGG} \rightarrow \mathrm{GAG}$ & non-conservative aa exchange in the mature protein & - A su I & $\begin{array}{l}\text { G in mouse; C. elegans, D. melanogaster } \\
\text { and Dictyostelium }\end{array}$ \\
\hline R $674 C^{c}$ & 1 & $\mathrm{CGC} \rightarrow \mathrm{TGC}$ & non-conservative aa exchange in the mature protein & - & $\begin{array}{l}\mathrm{R} \text { in mouse; C. elegans, D. melanogaster, } \\
\text { Dictyostelium and rice }\end{array}$ \\
\hline R676P & 1 & $\mathrm{CGG} \rightarrow \mathrm{CCG}$ & non-conservative aa exchange in the mature protein & +Eael & $\begin{array}{l}\mathrm{R} \text { in mouse; } \mathrm{D} \text {. melanogaster; } \mathrm{Q} \text { in } \\
\mathrm{C} . \text { elegans and Dictyostelium; S in rice }\end{array}$ \\
\hline $\begin{array}{l}\text { G737R } \\
\text { delG59 }\end{array}$ & 4(A 4\%; D 4\%) & $\begin{array}{l}\text { GGC } \rightarrow \text { CGC } \\
\text { GGGGGCG } \rightarrow \text { GGGG_CG }\end{array}$ & $\begin{array}{l}\text { non-conservative aa exchange in the mature protein } \\
\text { frameshift, premature termination at position } 120 \text { after } \\
101 \text { altered aa }\end{array}$ & $-\mathrm{Ncl} \mathrm{I}$ & $A$ in mouse \\
\hline del10bp503b & & $\operatorname{del}[G G A G C G G C C A]$ & $\begin{array}{l}\text { frameshift, premature termination at position } 184 \text { after } \\
13 \text { altered aa }\end{array}$ & & \\
\hline delTG 1035 & & GCTGTGTG $\rightarrow$ GCTG_TG & $\begin{array}{l}\text { frameshift, premature termination at position } 386 \text { after } \\
38 \text { altered aa }\end{array}$ & & \\
\hline delA 1317 & & GGTAG $\rightarrow$ GG_TG & $\begin{array}{l}\text { frameshift, premature termination at position } 474 \text { after } \\
35 \text { altered aa }\end{array}$ & & \\
\hline delA 2100 & & CAAAAAT $\rightarrow$ CAAAA_T & $\begin{array}{l}\text { frameshift, shifted termination to position } 823 \text { after } 44 \\
\text { altered and } 80 \text { additional aa }\end{array}$ & & \\
\hline del2bp2171 & & ACTGTGGA $\rightarrow$ ACTG_GA & $\begin{array}{l}\text { frameshift, shifted termination to position } 786 \text { after } 19 \\
\text { altered and } 43 \text { additional aa }\end{array}$ & & \\
\hline ins25bp48 & & $\begin{array}{l}\text { [GGGGC.....CGACG] } \\
\text { duplicated }\end{array}$ & $\begin{array}{l}\text { direct repeat of bp } 49-73 \text {, frameshift, premature } \\
\text { termination at position } 120 \text { after } 107 \text { altered aa }\end{array}$ & & \\
\hline ins7bp48 & & [GGGGCCG] duplicated & $\begin{array}{l}\text { direct repeat of bp 49-55, frameshift, premature } \\
\text { termination at position } 120 \text { after } 102 \text { altered aa }\end{array}$ & & \\
\hline ins5bp209 & & [GCGGC] duplicated & $\begin{array}{l}\text { direct repeat of bp } 210-214 \text {, frameshift, premature } \\
\text { termination at position } 120 \text { after } 46 \text { altered aa }\end{array}$ & & \\
\hline insA A 950 & & GATGC $\rightarrow$ GATAAGCA & $\begin{array}{l}\text { frameshift, premature termination at position } 338 \text { after } \\
22 \text { altered aa }\end{array}$ & & \\
\hline
\end{tabular}

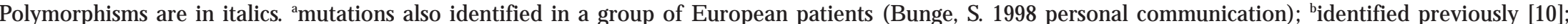
cidentified previously [3]. 
Table 4 Genotype and phenotype of patients

\begin{tabular}{|c|c|c|c|c|c|}
\hline & 1. Allele & 2. Allele & Polymorphism & Phenotype & $\begin{array}{l}\text { A ge at diagnosis } \\
\text { (years/month) }\end{array}$ \\
\hline 1 & - & - & G 737R & severe & 6 \\
\hline 2 & H 227P & P521L & & attenuated & 9 \\
\hline 3 & $\mathrm{~F} 48 \mathrm{~L}$ & $\mathrm{R} 297 \mathrm{X}$ & c54/c54 & attenuated & 12 \\
\hline 4 & R 297X & - & & severe & 19 \\
\hline 5 & V 334F & V 334F & & severe & 4 \\
\hline 6 & R 565W & - & & severe & 1 \\
\hline 7 & R 297X & del2bp2171 & & severe & $2 / 4$ \\
\hline 8 & P521L & P521L & & severe & 5 \\
\hline 9 & del10bp503 & H 414R & & severe & $3 / 2$ \\
\hline 10 & R $297 X$ & G 69S & c54/c54 & attenuated & $21 / 8$ \\
\hline 11 & G 292R & R 565W & & severe & $2 / 9$ \\
\hline 12 & - & - & & severe & 7 \\
\hline 13 & L 560P & & & attenuated & $21 / 5$ \\
\hline 14 & - & - & & severe & $2 / 6$ \\
\hline 15 & L 617F & - & & severe & $7 / 9$ \\
\hline 16 & W 404X & W 404X & & severe & $<1$ \\
\hline 17 & delG 59 & R 626X & & severe & $<1$ \\
\hline 18 & R 565W & - & & severe & 5 \\
\hline 19 & delTG 1035 & R 565P & & severe & 10 \\
\hline 20 & R 674C & G 650E & & severe & 14 \\
\hline 21 & F 410S & - & & severe & $8 / 8$ \\
\hline 22 & - & - & & severe & $4 / 5$ \\
\hline 23 & R 626X & R 626X & & severe & $3 / 5$ \\
\hline 24 & insA A 950 & - & G 737R & severe & 3 \\
\hline 25 & ins7bp48 & delA 2100 & & severe & $4 / 6$ \\
\hline 26 & ins25bp48 & delA 1317 & & severe? & ? \\
\hline 27 & - & - & & severe & 4 \\
\hline 28 & R 643C & - & & attenuated & 29 \\
\hline 29 & $\mathrm{R} 676 \mathrm{P}$ & R 297X & & severe & 5 \\
\hline 30 & R 297X & R 297X & $c 54 \mathrm{~g} / \mathrm{c} 54 \mathrm{~g}$ & severe & 6 \\
\hline 31 & R 643C & R 643C & & attenuated & 26 \\
\hline 32 & - & - & & attenuated & 22 \\
\hline 33 & - & - & & attenuated? & 5 \\
\hline 34 & ins5bp209 & R 297X & G 737R & severe & 9 \\
\hline 35 & R 297X & - & & severe & 6 \\
\hline 36 & R 297X & - & c54/c54 & attenuated & 32 \\
\hline 37 & - & - & & attenuated & 63 \\
\hline 38 & R 643C & R 643C & & attenuated & 28 \\
\hline 39 & $\mathrm{H} 248 \mathrm{R}$ & - & & attenuated & 45 \\
\hline 40 & W 494X & W 494X & G 737R/G 737R & severe & $<1$ \\
\hline
\end{tabular}

- not known; ? insufficient data. Patients 1 to 15 and 17 to 26 are from A ustralasia. Patients 27 to 39 are from The Netherlands. Patient 40 is from N orway. ${ }^{14}$ Patient 16 is from the $U$ nited States. 20

digestion with an appropriate restriction enzyme. Eighty of the controls were from Dutch individuals to allow the detection of population specific differences. The G737R allele was found on 12 control chromosomes and is therefore considered non-pathogenic.

The substitution of Cytosine54 by a Guanosine is clearly a polymorphism since it does not alter the encoded amino acid (A la18). It was found in homozygous form in a patient with R 297X / R 297X genotype (patient 30). The c54g polymorphism is not linked to $\mathrm{R} 297 \mathrm{X}$, since other patients with this allele (patients 3 ,
10 and 36) clearly have the wildtype sequence at position 54 .

\section{Genotype/Phenotype Correlation}

Classifying patients into different phenotypes is problematic since much of the available data are observations of individual clinicians and not directly comparable. We are therefore only able to distinguish between a severe and an attenuated phenotype depending on onset of symptoms, language development and onset of 
regression. Within these two groups there is still considerable variability in the disease progression.

Twenty-one of the A ustralasian MPS IIIB developed patients the classical severe Sanfilippo phenotype, whereas four patients developed the attenuated form of the disorder with later onset and/or slower regression. A s expected, all mutations resulting in premature termination either by a nonsense mutation or insertions and deletions lead to the severe phenotype (patients 17, 23, 26, 30 and 40). Similarly, the deletions masking the original stop codon and presumably elongating the gene product (del2bp2171 and delA 2100 in patients 7 and 25) confer a severe phenotype in combination with $\mathrm{R} 297 \mathrm{X}$ and ins7bp48. M issense mutations $\mathrm{V} 334 \mathrm{~F}$ and $\mathrm{P} 521 \mathrm{~L}$ also cause the severe phenotype when present on both alleles in patients 5 (V334F/V 334F) and 8 (P521L/P521L). However, in heterozygous form in combination with $\mathrm{H}$ 227P (patient 2) P521L leads to the attenuated clinical phenotype as does G69S in combination with $\mathrm{R} 297 X$ (patient 10). The other two patients with attenuated phenotype (patients 3 and 13) have F 48L/R 297X and L 560P/unknown genotypes.

The majority of Dutch patients show clinical symptoms consistent with the attenuated form of the disease. Patients 37 and 39 were only recently diagnosed at the age of 63 and 47 years respectively. Two of the attenuated cases (patients 31 and 38), who are apparently not related, were found to be homozygous for $\mathrm{R} 643 \mathrm{C}$, an allele that was also identified in an attenuated patient (patient 28) with an unknown second allele. Two patients (patients 35 and 36) with R 297X/unknown genotype have the severe and attenuated phenotype respectively, implying that the unknown alleles modify the severity of the clinical phenotype.

\section{Unstable Regions}

A plot of the mutations on to the gene structure (Figure 1) revealed a reasonably even distribution of mutations throughout the gene with the exception of a region that contains a direct repeat encoding the leader peptide and the putative signal peptidase cleavage site (bp 49-73). Three mutations (ins25bp48, ins7bp48 and delG 59), as well as a polymorphism (c54g), are located in this area. There also appears to be a cluster of mutations in the last third of exon 6. Two codons (arginine 565 and 643) also show some instability with different mutations affecting the same residue: $R$ 565P and R $565 \mathrm{~W}$, as well as R $643 \mathrm{H}^{10}$ and $\mathrm{R} 643 \mathrm{C}$.

\section{Frequencies}

Due to the observed strong allelic heterogeneity, frequencies for mutations are generally low. The most common mutation, R 297X, has an overall frequency of $12.5 \%$ ( 10 out of 80 alleles) and seems to be more common in the Dutch patient group where it accounts for $23 \%$ ( 6 out of 26 alleles), compared with $8 \%$ for the A ustralasian patients. Three alleles with the P521L mutation were identified, giving this amino acid exchange a frequency of $6 \%$ among A ustralasian patients. The second nonsense mutation, R 626X, was identified in two patients of South $E$ uropean and A sian background in homozygote and heterozygote form respectively, giving it a frequency of $6 \%$ in the A ustralasian group similar to R565W, which was

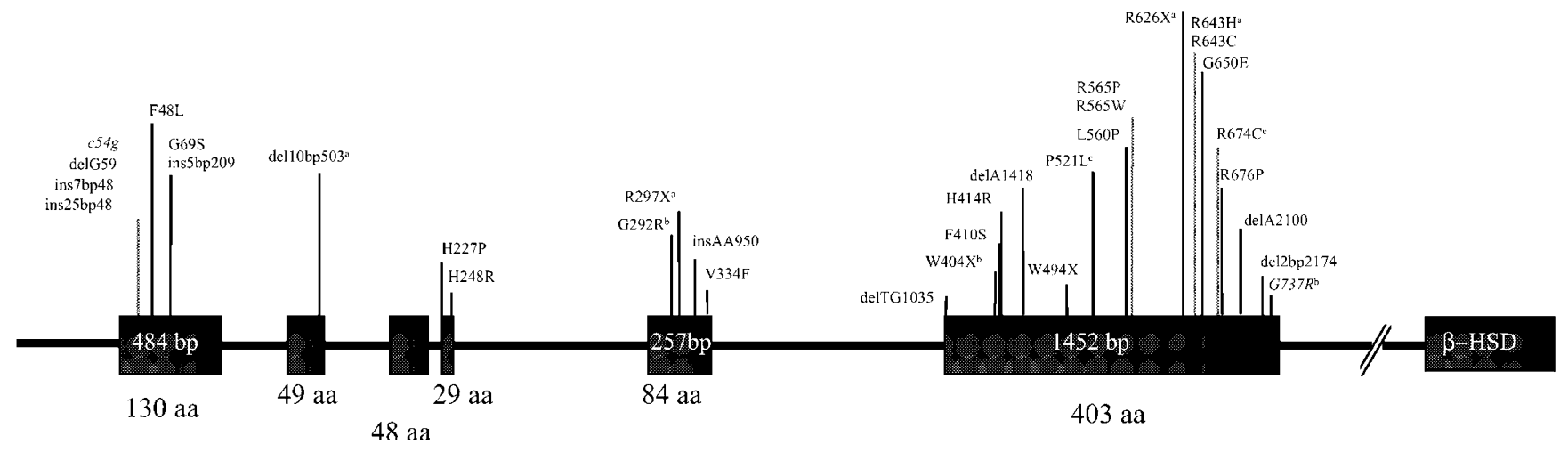

Figure 1 Novel polymorphisms are printed cursive. Exons are represented by boxes with the length in bp given for exon 1,5 and 6 . The number of amino acids encoded by the individual exons is printed underneath. ${ }^{\mathrm{M}} \mathrm{M}$ utations previously identified [10]. ${ }^{b} \mathrm{M}$ utations identified in a group of $\mathrm{E}$ uropean patients (Susanna Bunge, personal communication). ${ }^{\mathrm{C}} \mathrm{M}$ utations identified previously [3]. M utation 'hot-spots' are highlighted 
identified in three heterozygote patients. R643C accounts for $19 \%$ of the M PS IIIB alleles in the Dutch patients with two patients being homozygous and one being heterozygous, respectively. A II other mutations were only found in a single patient.

The G 737R polymorphism was identified on 12 out of 142 control alleles. A ustralasian and Dutch controls carry this polymorphism with similar frequencies, $7 \%$ and $9 \%$ respectively, whereas the frequencies in the two patient groups are slightly lower. Only $4 \%$ of Australasian and Dutch MPS IIIB patients carried the G 737R allele.

\section{Putative $\alpha-N$-acetylglucosaminidase Genes}

With the TBLA STN local alignment to ol ${ }^{21}$ the NA G LU protein sequence was used to search a non-redundant database compiled of the entries from GenBank and E M BL databases, including updates as of 17 February 1998 at the Australian National G enomic Information Service (ANGIS) for related sequences. A part from near-perfect alignments with various human genomic and CDNA clones isolated from different tissues and developmental stages and the mouse homolog ( $G$ enB ank U 85247), significant homologies $[P(N)<1.2 e-5]$ were found to different clones from Caenorhabditis elegans, D rosophila melanogaster, A rabidopsis thaliana, Dictyostelium discoideum and rice. These putative NAGL U genes appear to have highly conserved aminoacid sequence in several regions of the protein. Table 3 summarises the alignments in respect to the mutations and polymorphisms found in patients. No homologies to yeast genes were found, suggesting that yeast does not have any $\alpha-\mathrm{N}$-acetylglucosaminidase activity, or that a different type of enzyme is catalysing the reaction.

\section{Discussion}

We were able to identify $66 \%$ of the M PS IIIB alleles in the 40 patients studied. Since all intron/exon boundaries were included in the analysis, it is unlikely that splice-site mutations were missed. A Ithough no changes were observed in the SSCP patterns of PCR product 6 $\mathrm{VI}$, which consists of the $3^{\prime}$ non-translated region including the polyA -signal, we cannot exclude mutations in this region, since the sensitivity of SSCP decreases with increased length of the analysed fragment. ${ }^{22}$ Similarly, no changes were identified in the
$63 \mathrm{bp}$ of 5 non-translated region included in fragment 1 I. M utations further upstream of the gene or within the introns might influence the transcription rate and/or stability of the mRNA and can only be detected by determining the $\mathrm{mRNA}$ levels in patient cell lines.

No highly common mutations were identified in either of the two patient groups. O nly six mutations/ polymorphism ( $R$ 297X , P521L, R 565W, R 626X, R 643C and $G$ 737R ) were found in more than one patient, and $R 643 C$ is restricted to the $D$ utch patient group, whilst $R$ 626X was only found in A ustralasian patients. However, R 626X was reported earlier in an A merican patient and the deletion of $10 \mathrm{bp}$ at position 503 was identified in an Italian patient ${ }^{10}$ as well as being found on one allele in an Australasian patient. The P521L mutation, which has a frequency of $6 \%$ in A ustralasian patients, has been described in an A merican family. ${ }^{3}$ A dditionally, G 292R and W 404X have been identified in a European group of patients (Bunge $S$, personal communication), and R $674 C$ was found in an A merican family. ${ }^{3} \mathrm{All}$ other reported mutations appear to be unique so far.

The allelic heterogeneity that we observe in MPS IIIB patients compared with MPS IIIA patients is consistent with the greater clinical variability of MPS IIIB. MPS IIIA is considered to be generally more severe than MPS IIIB. ${ }^{1}$ In MPS IIIA one mutation ( $\mathrm{R} 245 \mathrm{H}$ ) accounts for over $30 \%$ of the alleles in A ustralasian ${ }^{23}$ and for nearly $60 \%$ of the alleles in Dutch patients, conferring the severe phenotype. ${ }^{24}$ Frequencies for mutations in M PS IIIB are much lower, with R 297X accounting for $8 \%$ and $23 \%$ in the A ustralasian and Dutch patients, respectively, explaining the greater severity as well as the reduced clinical variability M PS IIIA compared to M PS IIIB. The low frequency of individual mutations makes it unlikely that mutation screening will improve the accuracy of the initial diagnostic procedures based on the analysis of metabolites and the determination of enzyme activity, the latter being sensitive enough for prenatal diagnosis. ${ }^{25,26}$ However, mutation analysis will allow carrier-testing for siblings, especially if a partner is consanguineous, and will enable a more accurate prognosis for families of newly diagnosed patients, thereby improving genetic counselling. M utation analysis is also of great importance for the selection of patients for trials of enzyme or gene replacement therapies and the evaluation of the efficacy of the protocols. Knowing the genotype of each treated patient might give an insight into the normal clinical 
variations and adverse immunological reactions and thus improve the interpretation of the results of these trials.

R 643C seems to be a Dutch MPS IIIB allele. The frequency of $23 \%$ is similar to the frequency of the $\mathrm{R} 297 \mathrm{X}$ allele in this patient cohort but, in contrast to the truncated protein, $\mathrm{R} 643 \mathrm{C}$ mutant protein seems to have some residual activity that leads to the attenuated clinical phenotype. A ttempts to measure residual activities with fluorogenic substrate in skin fibroblasts were not successful and will have to be done with either natural substrate or with overexpressed mutant protein. Patients 31 and 38 are homozygous for the R643C allele. They were reported to have slow early development, but learned to speak. R egression of intellectual abilities and motor skills was not observed until they were in their late teens and early twenties, respectively. The two families, although apparently not related, are from the same geographical area which suggests a founder effect. D etailed clinical descriptions of patient 31 and her affected siblings and cousins are available. $^{27,28}$

A Ithough most of the mutations in the Australasian MPS IIIB patient cohort seem to result in the severe phenotype, there are four attenuated cases with H 227P/P521L (patient 2), F48L/R 297X (patient 3) G 69S/R 297X (patient 10) and L560P/unknown (patient 13) genotype. Since P521L and R $297 X$ cause a severe phenotype in homozygous form (patients 8 and 30 ) it is likely that F 48L, G 69S and H 227P allow enough active enzyme to be produced to delay onset and progression of the disease. The other novel missense mutations (V 334F, F 410S, H 414R, R 565W/P, L617F, G 650L and $R 676 P$ ) are associated with severe clinical phenotypes.

The identification of a homozygous nonsense mutation in the NAGLU gene of patient $16,{ }^{20}$ also proves that MPS IIIB and the glycogen storage disease, from which this patient also suffered, are not linked to each other, nor is the MPS IIIB phenotype due to the 12:20 translocation. This was obvious after the NAGLU gene was located on chromosome $17 .^{8-10}$

Since the three-dimensional structure of NAGLU is unknown, speculation about the effect of these amino acid exchanges on the structure is not possible. Furthermore, we cannot exclude that some changes may be rare polymorphisms, although none of them were found on a relatively large number of control chromosomes. A Iso, except for H414R, the amino acid exchanges are non-conservative and differences in amino acid size and charge are expected to have an impact on the enzyme. U Itimately, expression studies are necessary to prove the detrimental effect of these amino acid exchanges on enzyme activity and/or stability.

The G 737R polymorphism is clearly non-pathogenic since it was found on 12 of the 142 control chromosomes. The slightly lower frequency of this allele in the two patient groups is due to the fact that those mutations which were identified in more than one patient (R643C, R 297X, P521L and R565W) have occurred on the wildtype background. It remains to be seen whether the exchange of $\mathrm{G} 737$ by arginine has any modifying effect on the enzyme function. However, G 737R can be ruled out as a candidate for the proposed 'hyperactive' allele(s), since it was identified in homozygous form in patient 40 , described by Pande et al. ${ }^{14}$ In this family some of the obligate carriers had enzyme activity within the normal range, thought to be due to a putative 'hyperactive' allele. Identification of allele(s) with higher enzymatic activity might be important with respect to the development of therapies as well as giving insights into the catalytically important structures of the enzyme.

A lthough the second polymorphism, c54g, was not systematically screened for, it was found in homozygous form in patient 30 ( $R$ 297X/R 297X). No linkage of $c 54 \mathrm{~g}$ to the $R 297 X$ allele was found, since other patients with this nonsense mutation have the wildtype cytosine at position 54. c54 is located within a region of high mutation frequency and it seems likely that the exchange of c54 occurred on the R 297X allele. Two insertions (direct repeats) and a deletion were identified within a stretch of 21 uninterrupted $C p G$ s containing a direct repeat [CCGGGG]. CpG dinucleotides are known ${ }^{29}$ to be hot spots for mutations similar to repeats within the sequence. In case of the latter, this is presumably caused by a slipped strand mispairing mechanism. ${ }^{30}$

The relative instability of $C p G$ dinucleotides might also contribute to some mutations arising independently in the same codon which was found in $\mathrm{R} 565 \mathrm{~W} / \mathrm{P}$, $\mathrm{R} 643 \mathrm{C} / \mathrm{H}^{10}$ and $\mathrm{R} 674 \mathrm{C} / \mathrm{H} .{ }^{3}$ Similar multiple mutations were also observed in MPS IIIA (amino acids R 74 and R 377), ${ }^{23,31,32}$, M PS I, ${ }^{33}$ and disorders other than lysosomal storage diseases. ${ }^{34-36}$ Two of the six arginine codons constitute $\mathrm{CpG}$ dinucleotides and in the above amino acid exchanges these two codons are mutated.

The apparent clustering of mutations in the last third of exon 6 (amino acids 612 to 737) might be coincidental, since no significant differences in this area 
compared with the neighbouring sequence were found with respect to $G C$ content or the number of $C p G$ dinucleotides. A Iternatively the apparent clustering might reflect a higher efficiency of the mutation detection method (SSCP) in this area, since mutations detected by direct sequencing of patient genomes are not clustered in this region. ${ }^{3} \mathrm{~A}$ nother possible explanation is that the DNA structure leaves this area more vulnerable to mutagenic events than other parts of the gene. A suggested ${ }^{16}$ crucial role of the carboxy end of the protein in enzyme structure/function cannot necessarily be assumed.

A database search for homologous proteins, in order to identify motifs and conserved regions of the enzyme, revealed a number of putative NAGLU genes of different species, ranging from the slime mould Dictyostelium to mice. U nfortunately, the NA G LU protein sequence aligned to partial CDNA s, genomic clones or EST $s$ and therefore it is not possible to distinguish between regions that are not conserved and those which are not in the database. Thus predictions of important protein functions from evolutionary conserved regions cannot be made.

The attenuated clinical phenotype is thought to result from the presence of a low level of residual enzyme activity delaying the storage of heparan sulphate and thereby the onset and progression of symptoms. M utations like R $643 \mathrm{C}$ that are associated with this phenotype are therefore expected to produce active enzyme, possibly with strongly altered properties. Expression of mutants with some residual activity and analysis of enzyme stability, localisation and catalytic properties might enable some predictions of structure/function relationship and will be useful in interpreting future crystallographic data.

\section{Acknowledgements}

We thank the patients' families for their support and Greta $\mathrm{R}$ ichardson for tissue culture. The referral of patient cell lines and clinical data by colleagues from Australasia, by $\mathrm{Dr} U$ M oog, Clinical G enetics Centre, M aastricht, The N etherlands (patients 37-39), and Dr G Hug, The Children's Hospital Medical Center, Cincinnati (patient 16), is greatly acknowledged. This work was supported by grants from the $\mathrm{N}$ ational $\mathrm{H}$ ealth and R esearch Council of A ustralia, the Women's and Children's Hospital Research Foundation and the MPS Society (USA).

\section{References}

1 Neufeld EF, M uenzer J: The mucopolysaccharidoses. In: Scriver CR, B eaudet AL, Sly WS and Valle D (eds). The Metabolic and Molecular B asis of Inherited D isease 7th edn. M cG raw-H ill: N ew York, 1995, pp 2465-2494.

2 A ndria G, Di Natale P, Del Guidice E, Strisciuglio P, M urino P: Sanfilippo B syndrome (M PS IIIB): attenuated and severe forms within the same sibship. Clin $G$ enet 1979; 15: 500-504.

3 Zhao HG, A ronovich E L, Whitley CB : G enotype-phenotype correspondence in Sanfilippo syndrome type B. A m J H um G enet 1998; 62: 53-63.

4 van de Kamp JJP, N iermeijer M F, von Figura K, G iesberts $\mathrm{M} \mathrm{A} \mathrm{H}$ : $\mathrm{G}$ enetic heterogeneity and clinical variability in the Sanfilippo syndrome (types A , B and C). Clin G enet 1981; 20: 152-160.

5 Beratis NG, Sklower SL, Wilbur L, M atalon R: Sanfilippo disease in G reece. Clin G enet 1986; 29: 129-132.

6 M ichelakakis H, Dimitriou E, Tsagaraki S, Giouroukos S, Schulpis K, Bartsocas CS: Lysosomal storage diseases in G reece. G enet Couns 1995; 6: 43- 47.

7 OMIM No. 252900 and No. 252920.

8 Zhao H, Lopez R, R ennecker J, Neufeld E F: Sanfilippo syndrome type $B$ : CDNA and gene encoding human $\alpha-\mathrm{N}$-acetylglucosaminidase. A m J H um Genet 1994; 55: A bstract 1473.

9 Weber B, B lanch L, Clements PR, Scott H S, Hopwood JJ : Cloning and expression of the gene involved in Sanfilippo B syndrome (M ucopolysaccharidosis III B). Hum Mol G enet 1996; 5: 771-777.

10 Zhao HG, Li HH, Bach G, Schmidtchen A, Neufeld EF: The molecular basis underlying Sanfilippo syndrome type B. Proc Natl A cad Sci USA 1996; 93: 6101-6105.

11 Vance J M, Pericak-Vance M A, E Iston R C et al: Evidence of genetic variation for $\alpha-\mathrm{N}$-acetyl-D-glucosaminidase in black and white populations: A new polymorphism. A m J Med Genet 1980; 7: 131-140.

12 Pericak-Vance MA, Vance J M, Elston RC, Namboodiri $K K$, Fogle TA: Segregation and linkage analysis of $\alpha-N$-acetyl-D -glucosaminidase (NAG) levels in a black family. A m J M ed G enet 1985; 20: 295-306.

13 Vance J M , Coneally PM, Wappner R, Yu PL, Brandt IK, Pericak-Vance MA: Carrier detection in Sanfilippo syndrome type B: report of six families. Clin G enet 1981; 20: 135- 140.

14 Pande $H$, Chester A, Lie $H$, Thorsby $E$, Stormorken $H$ : Concomitant occurence of Mucopolysaccharidosis IIIB and G lanzmann's thrombasthenia. Further evidence of a hyperactive $\alpha-\mathrm{N}$-acetylglucosaminidase-producing allele. Clin G enet 1992; 41: 243-247.

15 A ronovich $E L$, Zhao $H G$, Neufeld $E F$, Whitley $C B$ : Mutation analysis in Sanfilippo syndrome type $B$ by automated sequencing of the NA GLU coding region. A m J H um G enet 1996; 59: A bstract 1418.

16 Schmidtchen A, G reenberg D, Zhao HG et al: NAGLU mutations underlying Sanfilippo syndrome type B. A m J H um G enet 1998; 62: 64-69.

17 Scott HS, Litjens T, N elson PV, Brooks DA, Hopwood JJ, M orris CP: $\alpha$-L -iduronidase mutations (Q 70X and P533R) associated with a severe $\mathrm{H}$ urler phenotype. $\mathrm{H}$ um $\mathrm{M}$ utat 1992; 1: 333-339. 
$18 \mathrm{M}$ arsh J, Fensom A H : 4-methylumbelliferyl $\alpha-\mathrm{N}$-acetylglucosaminidase activity for diagnosis of Sanfilippo B disease. Clin G enet 1985; 27: 258-262.

19 H opwood J J, E lliott H : D etection of the Sanfilippo type B syndrome using radiolabelled oligosaccharides as substrates for the estimation of $\alpha-\mathrm{N}$-acetylglucosaminidase. Clin Chim A cta 1982; 120: 77-86.

$20 \mathrm{M} \mathrm{clntire} \mathrm{SC,} \mathrm{Bansal} \mathrm{V,} \mathrm{Wenger} \mathrm{SL} \mathrm{et} \mathrm{al:} \mathrm{G} \mathrm{lycogen} \mathrm{storage}$ disease and Sanfilippo syndrome type $B$ in a patient with 12:20 translocation. A m J H um G enet 1993; 53: A bstract 927.

21 A Itschul SF, Gish W, Miller W, Myers EW, Lipman DJ: Basic local alignment search tool. J Mol Biol 1990; 215: 403-410.

$22 \mathrm{H}$ ayashi $\mathrm{K}, \mathrm{Y}$ andell DW: How sensitive is PCR -SSCP? H um M utat 1993; 2: 338-346.

23 Weber B, Guo X-H, W raith JE et al: Novel mutations in Sanfilippo A syndrome: I mplications for enzyme function. H um M ol G enet 1997; 6: 1573-1579.

24 Weber B, van de Kamp JJP, K leijer WJ et al: I dentification of a common mutation ( $\mathrm{R} 245 \mathrm{H}$ ) in Sanfilippo A patients from The Netherlands. J Inherit M etab $D$ is 1998; in press

25 K leijer WJ, Huijmans J G, B lom W et al: Prenatal diagnosis of Sanfilippo disease type B. Hum Genet 1984; 66: 287-288.

26 M inelli A, Danesino C, L o-Curto F et al: First trimester prenatal diagnosis of Sanfilippo disease (MPSIII) type B. Prenat Diagn 1988; 8: 47-52.

27 van de Kamp JJP, van Pelt J F, Liem KO, G iesberts M A H, $\mathrm{N}$ iepoth LTM, Staalman CR : Clinical variability in Sanfilippo B disease: a report on six patients in two related sibships. Clin G enet 1976; 10: 279-284.
28 van Schrojenstein-de Valk HMJ, van de Kamp JJP: Follow-up on seven adult patients with mild Sanfilippo B-disease. A m J M ed G enet 1987; 28: 125-129.

29 Cooper DN, K rawczak M, A ntonarakis SE M: The nature and mechanisms of human gene mutation. In: Scriver $C R$, Beaudet A L, Sly WS, Valle D (eds). The M etabolic and Molecular Basis of Inherited Disease, 7th edn. M cG rawH ill: New York, 1995, pp 259-292.

30 Cooper DN, K rawczak M: M echanisms of insertional mutagenesis in human genes causing genetic disease. $\mathrm{H}$ um G enet 1991; 87: 409-415.

31 Bunge $\mathrm{S}$, Ince $\mathrm{H}$, Steglich $\mathrm{C}$ et al: Identification of 16 sulfamidase gene mutations including the common R 74C in patients with Mucopolysaccharidosis type IIIA (Sanfilippo A ). H um M utat 1997; 10: 479-485.

32 Di Natale P, Balzano N, Esposito S, Villani GRD: Identification of molecular defects in I talian Sanfilippo A patients. Hum Mutat 1998; in press

33 Scott HS, Bunge $S, G$ al A, Clarke LA, Morris $C P$, Hopwood J J: Molecular genetics of Mucopolysaccharidosis Type I: diagnostic, clinical and biological implications. H um M utat 1995; 6: 288-302.

34 Kotze MJ, Loubser 0 , Thiart R et al: CpG hotspot mutations at the $L D L$ receptor locus are a frequent cause of familial hypercholesterolaemia among South A frican Indians. Clin G enet 1997; 5: 394-398.

$35 \mathrm{M}$ unier $\mathrm{FL}$, Korvatska $\mathrm{E}, \mathrm{D}$ jemai $\mathrm{A}$ et al: Kerato-epithelin mutations in four $5 q 31$-linked corneal dystrophies. Nat G enet 1997; 15: 224-225.

36 Vihinen $M$, B elohradsky BH, H aire R N et al: BTK base, mutation database for $X$-linked agammaglobulinemia (XLA ). Nucleic A cids Res 1997; 25: 166-171. 